\title{
Defining adult bonefish (Albula vulpes) movement corridors around Grand Bahama in the Bahamian Archipelago
}

\author{
Karen J. Murchie • Aaron D. Shultz • Jeffrey A. Stein • \\ Steven J. Cooke • Justin Lewis • Jason Franklin • Greg Vincent • \\ Edward J. Brooks • Julie E. Claussen • David P. Philipp
}

Received: 14 November 2014 / Accepted: 28 May 2015 /Published online: 6 June 2015

(C) Springer Science+Business Media Dordrecht 2015

\begin{abstract}
Development on Grand Bahama in the Bahamian Archipelago during the 1950's to 1970's resulted in substantial changes to the island's geography. Hawksbill Creek, which potentially served as a natural migration route for fish from the north side to the south side of the island, was severed and replaced by a man-made canal called the Grand Lucayan Waterway (GLW). Bonefish (Albula spp.), a sport-fish that contributes more than \$141 million to the Bahamian economy annually, is one such species that may have been affected. The purpose of this study was to determine contemporary movement corridors of adult bonefish during their spawning season (October to May) in Grand Bahamian waters. This was accomplished by using a passive
\end{abstract}

K. J. Murchie $(\bowtie)$

Department of Biology, College of The Bahamas, Freeport, Grand Bahama F-42766, The Bahamas

e-mail: kmurchie@cob.edu.bs

A. D. Shultz · J. A. Stein · D. P. Philipp

Department of Natural Resources and Environmental

Sciences, University of Illinois, 1102 S. Goodwin Ave., MC

047, Urbana, IL 61801, USA

A. D. Shultz

Flats Ecology and Conservation Program, Cape Eleuthera

Institute, Eleuthera, The Bahamas

J. A. Stein · J. E. Claussen · D. P. Philipp

Illinois Natural History Survey, University of Illinois, 1816 S.

Oak St., Champaign, IL 61820, USA

\section{J. A. Stein · J. E. Claussen - D. P. Philipp}

Fisheries Conservation Foundation, 1816 S. Oak St.,

Champaign, IL 61820, USA acoustic telemetry array of 17 receivers and 30 transmitter-implanted individuals. A total of 26,108 detections were logged from 20 of the fish. Eight bonefish tagged on the north side used the GLW to access waters on the south, whereas no transmitter-implanted fish tagged on the south side fully traversed the man-made canal, suggesting that primary spawning areas may be located on the south side of the island. This result is consistent with previous reports that bonefish spawn near deep water which is easier to access on the south side of Grand Bahama. Further supporting this finding, two other bonefish tagged on the north side forayed around the east end of the island and were detected on receivers approximately $88 \mathrm{~km}$ from their tagging

\section{S. J. Cooke}

Fish Ecology and Conservation Physiology Laboratory, Department of Biology and Institute of Environmental Science, Carleton University, 1125 Colonel By Drive, Ottawa, Ontario K1S 5B6, Canada

\section{J. Lewis}

Environment Department, University of York, York YO10

5DD, UK

J. Franklin $\cdot$ G. Vincent

h2obonefishing, Grand Bahama, The Bahamas

\section{E. J. Brooks}

Shark Research and Conservation Program, Cape Eleuthera Institute, Eleuthera, The Bahamas 
locations. Additionally, two other bonefish tagged on the north side were detected at the west end of the island, with one individual continuing its movements along the south side of the island for an approximate straight-line distance of $80 \mathrm{~km}$. Canal use typically corresponded to days immediately prior to or after new or full moons, indicating that movements were related to spawning. This study suggests that despite historical habitat modifications, bonefish today use the GLW as a movement corridor for migrations during spawning season, emphasizing the importance of protecting the canal from any activities that could impede connectivity.

Keywords Bonefish - Acoustic telemetry P Prespawning aggregations

\section{Introduction}

Coastal marine ecosystems represent some of the most altered ecosystems on the planet (Halpern et al. 2008), having been dramatically transformed by human development activities associated with industry, urbanization, and tourism (Lotze et al. 2006). Although this is a global concern, coastal ecosystems in tropical and subtropical regions typically characterized by mangrove forests, coastal wetlands, and tidal creeks, are particularly sensitive to disruptions (Alongi 2002; Polidoro et al. 2010). When pristine or largely intact, these near-shore ecosystems are biologically complex (Feller et al. 2010) and highly productive, with many ecologically and economically important fish and invertebrates using such habitats for reproduction or juvenile rearing (Faunce and Serafy 2006; Nagelkerken et al. 2008). In the Caribbean, most islands once contained rich and expansive natural coastal regions with interconnected natural channels and tidal creeks, but as a result of developmental pressures, largely for tourism and urban infrastructure, much of those habitats have been altered (McElroy and de Albuquerque 1998).

Grand Bahama is the second most developed island in the archipelago nation of The Bahamas (Buchan 2000). During the 1950's through to the 1970's, two substantial hydrological changes were made to Grand Bahama, primarily in the Freeport and Lucaya areas (Barratt 2002). The first notable change was the closing of Hawksbill Creek, a natural tidal creek waterway passing through the island west of Freeport. Road construction and development of a ship harbour eliminated this channel as a potential migration route for fish between the north and south sides of the island (G. Waugh pers. comm.). Anecdotally, bonefish (Albula spp.) historically used Hawksbill Creek as a migration route (K. Cooper pers. comm.). The second notable change was the construction of the Grand Lucayan Waterway (GLW), a man-made channel that bisected the island to the East of Freeport and effectively re-linked the Little Bahama Bank on the north to the deep waters of the Northwest Providence Channel on the south (Dupuch 1971) (Fig. 1). To date no one has studied how fish use this waterway.

Bonefish are an important sport fish to the Bahamian economy, with the economic impact of the fishery exceeding \$141 million annually (Fedler 2010). Additionally, bonefish play an important ecological role by moving nutrients among habitats in coastal systems (Murchie et al. 2013) and influencing benthic prey distribution (Engstrom 1984). Because bonefish are often found in large schools (Johannes and Yetting 2000; Danylchuk et al. 2011) they can make up a substantial portion of fish biomass in the tidal flat areas they inhabit. While scientific knowledge on bonefish has increased tremendously in the last decade (see Ault 2008; bonefish biology reviewed in Adams et al. 2013), fundamental ecological insights are still lacking in many areas of the life history. From a fisheries conservation and management perspective, one pressing need for research is to gain a better understanding of the spatial ecology of bonefish during their spawning season.

In The Bahamas working near Cape Eleuthera, Danylchuk et al. (2011) were the first to describe bonefish pre-spawning aggregations along with their courtship behaviours and spawning activities. The documentation by Danylchuk et al. (2011) of the dynamics of pre-spawning aggregations demonstrates the potential for vulnerability to overharvesting bonefish from intense fishing pressure (Coleman et al. 1996; Domeier and Colin 1997; Roberts and Hawkins 1999; Musick et al. 2000; Sala et al. 2003). Locating the prespawning aggregation near Cape Eleuthera was accomplished through a study that documented movement during the (October to May) spawning season of individual bonefish from their typical feeding grounds in tidal creeks along the shoreline to the end of Cape Eleuthera for spawning (Murchie et al. 2013). Further bonefish tracking by Danylchuk et al. (2011) revealed short duration off-shore movements to deep water during the night for actual spawning. The purpose of this 
Fig. 1 The Grand Lucayan waterway looking south, with a view of the channelized, concrete retaining walls. Photo courtesy GBPA / TheBahamasWeekly.com

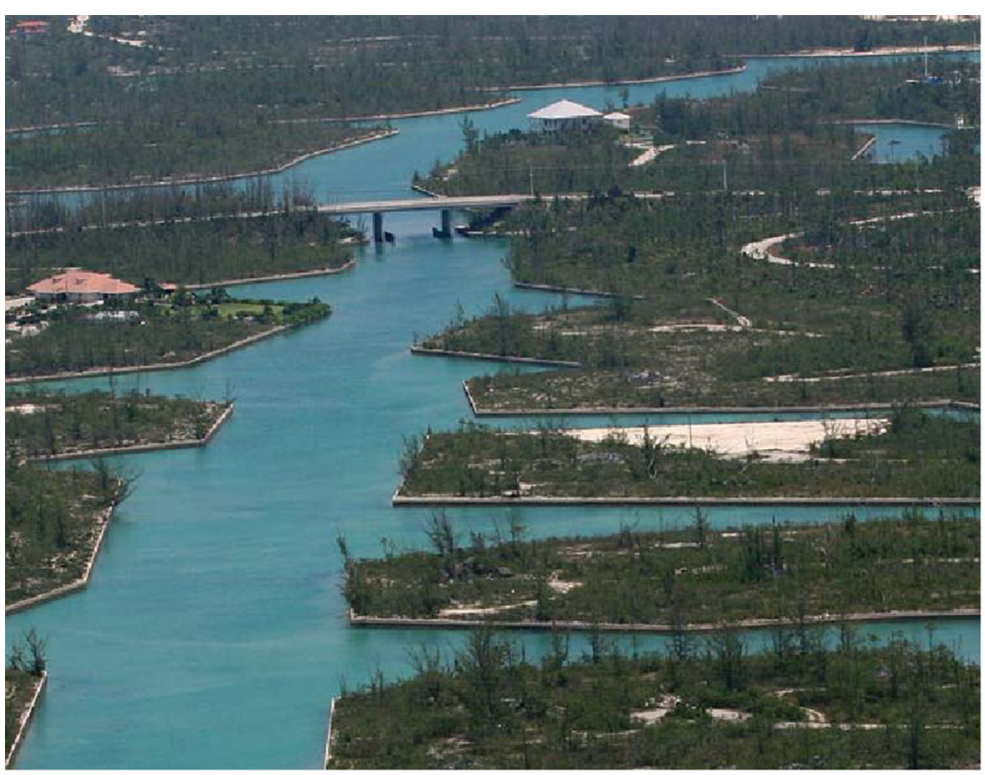

study was to determine contemporary movement corridors of adult bonefish during their spawning season in Grand Bahamian waters. Doing so would enable future tracking studies to identify specific sites of prespawning aggregations and nocturnal spawning locales. From an applied perspective, knowing if bonefish use the GLW is important for understanding its current ecological role in supporting economically important fisheries, as well as for informing the Bahamian government about the potential impacts of proposed development and for identifying areas that might benefit from habitat enhancement. More broadly, the approach used here is transferrable to other coastal species and emphasizes how fish interact with human-altered habitats.

\section{Materials and methods}

This study was conducted in the waters surrounding the $1378 \mathrm{~km}^{2}$ island of Grand Bahama, The Bahamas $\left(26^{\circ}\right.$ $\left.39^{\prime} 0^{\prime \prime} \mathrm{N}, 78^{\circ} 19^{\prime} 0^{\prime \prime} \mathrm{W}\right)$ (USACE 2004). Grand Bahama has extensive mangrove wetlands along the northern and eastern shorelines of the island, and in general contains a number of different habitats such as tidal creeks, sand and mud flats, beach strand and rocky shorelines (Sullivan Sealey et al. 2002). Semi-diurnal tidal cycles with maximal daily ranges of $1.3 \mathrm{~m}$ occur in this area.

Between October 25 and October 29, 2013, 30 bonefish $(545 \pm 58 \mathrm{~mm}$ total length; mean $\pm \mathrm{SD})$ were implanted with acoustic transmitters (model V13 coded tags, $13 \mathrm{~mm}$ diameter, $36 \mathrm{~mm}$ long, $6 \mathrm{~g}$ in water, 45 to $135 \mathrm{~s}$ random on/off time, 513 day battery life: Vemco Inc., Shad Bay, NS) following the methods outlined by Wagner et al. (2011). Bonefish were captured either by angling (i.e., conventional fly fishing gear) or via seine net ( $2.5 \mathrm{~cm}$ mesh, $91.4 \mathrm{~m}$ long) in one of six different zones around Grand Bahama (Fig. 2). Captured bonefish were held in flow-through holding pens $(82 \mathrm{~cm} \mathrm{x}$ $52 \mathrm{~cm} \mathrm{x} 42 \mathrm{~cm}$ ) submerged in a minimum of $0.6 \mathrm{~m}$ of water where they were held until surgery. Bonefish were anesthetized with eugenol prior to surgery $(30 \mathrm{mg} / \mathrm{L})$ and then placed supine on a piece of foam covered with anti-slip material on a flow-through surgery table. Stage- 4 anesthesia was reached in less than $3 \mathrm{~min}$. A maintenance dose of eugenol $(10 \mathrm{mg} / \mathrm{L})$ was supplied to the gills of the fish via recirculating seawater. To implant the transmitter, a small $(2-3 \mathrm{~cm})$ incision was made on the ventral midline, posterior to the pectoral fins. After being disinfected with an iodine solution, the transmitter was inserted and gently guided into the coelomic cavity, anteriorly toward the pectoral fins. The incision was closed with two simple interrupted sutures using monofilament absorbable suture material (Ethicon 3-0 PDS II, Johnson and Johnson, New Jersey). Where possible, the sex of the fish was determined via internal examination. The fish was then measured for fork length ( $\mathrm{mm}$ ) and was marked externally with a plastic-dipped dart tag (model PDL, 85 mm, Hallprint, Hindmarsh Valley, South Australia) as part of an on-going mark-recapture 
program with the Bonefish and Tarpon Trust. The entire procedure generally took less than $5 \mathrm{~min}$. Recovery from anesthesia (i.e., regaining equilibrium) typically took less than $1 \mathrm{~min}$. Following recovery from anesthesia, bonefish were held for up to $1 \mathrm{~h}$ in the flow-through net pens to fully recover from surgery. All surgeries were conducted by two experienced surgeons.

Bonefish movements were primarily tracked through the use of a passive telemetry array. Between October 21 and October 24, 2013, and prior to implanting adult bonefish with electronic tags, 17 acoustic receivers (VR2W model, Vemco Inc., Shad Bay, NS) were strategically placed around the island (Fig. 3). Acoustic receivers were positioned to ensure extensive coverage of the GLW, and the outlets on both the north and south ends of the canal, with remaining receivers positioned to determine bonefish movements past the east and west ends of the island, as well as along the southern shore of Grand Bahama (Fig. 3). The average depth of the receivers was $2.5 \mathrm{~m}$ (range: $1.5-5.0 \mathrm{~m}$ ). All receivers had a minimum coverage radius of $250 \mathrm{~m}$, with deeper stations having a coverage radius of $400 \mathrm{~m}$. Wind and wave conditions as well as tidal cycles influence the detection range of individual receivers (Heupel et al. 2006). Receivers were downloaded both mid-study (January 20, 2014) and when they were removed permanently (June 20-21, 2014). Data were imported into the VUE database (Vemco Inc, Shad Bay, NS) and then individual fish files were exported into Excel for analyses. Movement data were examined by plotting a timecourse of receivers visited. Moon phases were referenced for bonefish migration through the GLW.

To supplement the passive telemetry array, manual tracking was conducted on seven days between the period of December 17, 2013 and February 2, 2014 using a portable receiver and hydrophone (VR100, Vemco Inc., Halifax, NS). Manual tracking was conducted from a boat and involved the manual hydrophone being lowered to a depth of 1-2 $\mathrm{m}$ below the water's surface. A minimum of 5 min listening time at discrete locations along the south shore of Grand Bahama was conducted to allow for presence/ absence determinations of transmitter-implanted fishes given the burst interval of the coded transmitters (i.e., min and $\max 45$ to $135 \mathrm{~s}$ ). When tagged fish were detected, the transmitter ID was recorded. Visual assessments of all areas were made to look for aggregations of bonefish so that fish numbers and their behaviours could be recorded.

\section{Results}

Out of the 30 bonefish implanted with transmitters, 20 (i.e., $67 \%$ ) were detected by the telemetry array after release (Table 1). Of the ten bonefish not detected postrelease (which were all tagged on the north side), one individual (tag \#29) was observed by researchers to be killed by a lemon shark (Negaprion brevirostris) shortly after release. From the 20 bonefish that were detected during the study period, a total of 26,108 detections were logged on the receivers, with bonefish \#22 responsible for $60.5 \%$ of the detections (Table 1). Bonefish \#22 was detected a total of 159 days moving between five different receivers (Fig. 3; Table 1), with most (96\%) of the detections logged on receiver 6 (Fig. 4). Receiver 6 was located just to the east of the southern mouth of the GLW, and was close to the implantation location for the bonefish tagged in Zone 6. No bonefish tagged in Zone 6 fully traversed the GLW through to the north side of the island, although bonefish \#27 was detected as far as two-thirds of the way to the north end (Table 1).

Eight bonefish that were tagged on the north side of Grand Bahama (i.e., in Zones 1-5), however, used the GLW to access waters on the south side of the island (Table 1). The timing of these north to south migrations through the canal typically corresponded to periods of 1 to 4 days before or after the full or new moon, suggesting that these movements were related to a spawning migration (Table 2). For example, on February 3, 2014, 4 days after the new moon, two bonefish (\#12 tagged in Zone 5 and \#37 tagged in Zone 3) were detected making a migration through the GLW on their way to receiver 13 on the south side of the island (Table 2). These individual fish entered the canal at different times of the day (at $15: 06$ and 8:23, respectively) but were close to leaving the canal at the same time (at 19:03 and 18:49, respectively). Bonefish \#12 was detected at receiver 13 at 20:51 and bonefish \#37 was detected at receiver 13 at 20:22. On March 18, 2014, 2 days after the full moon, three bonefish (\#12 tagged in Zone 5, \#24 and \#25 tagged in Zone 3) were recorded making a north-south migration through the canal. Three days later, on March 21, 2014, bonefish \#12 and \#25 were detected making a south-north migration through the canal along with bonefish \#36 (Table 2). Bonefish \#12 can be seen repeatedly using the GLW on the same dates as individuals tagged in the same school from Zone 3 on a number of occasions (Table 2, Fig. 5). Adult bonefish typically 


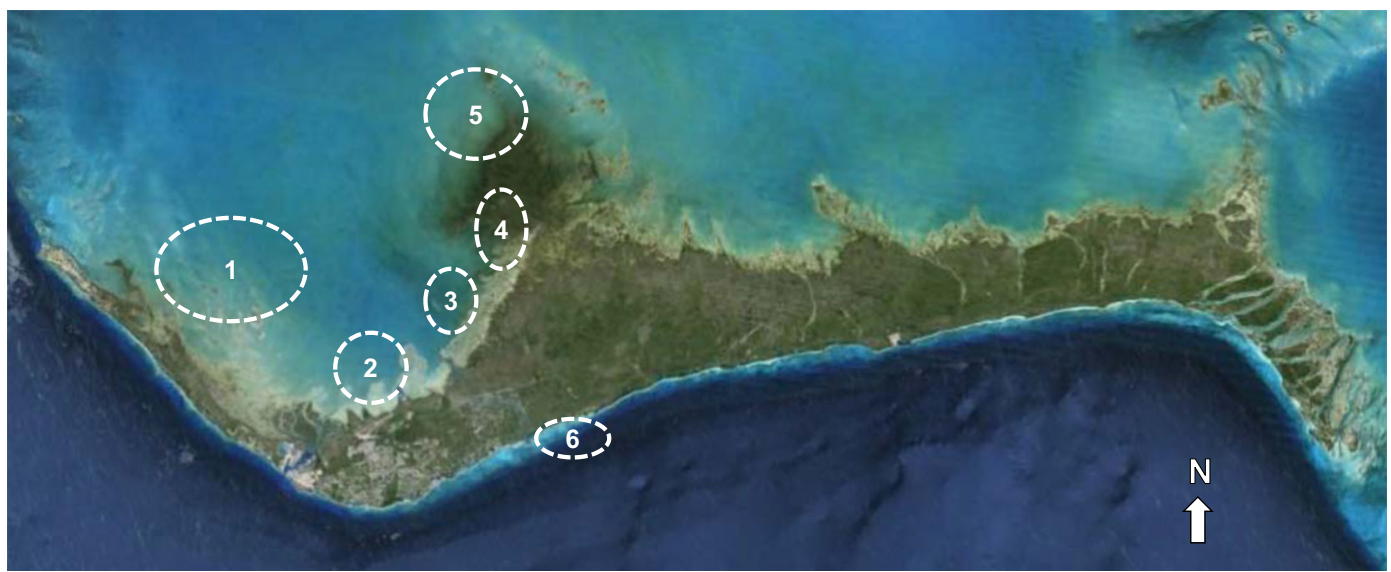

Fig. 2 Study area surrounding Grand Bahama showing the six different zones where adult bonefish were implanted with acoustic transmitters

were at-large on the south side of the island for two to 3 days before migrating back to the north side of Grand Bahama (Table 2; Fig. 4)

Not all bonefish used the GLW to access waters on the south side of the island. Two bonefish tagged in Zone 1 were detected at the west end of the island (Table 1), each on two separate occasions that corresponded to a period of 1-4 days either before or after the full or new moon. Bonefish \#33, had detections on the west end with a period of 46 days in between. On the second visit to the west end receivers, bonefish \#33 continued on to receiver 6 on the south side, all the way to the east of the GLW (Fig. 6a). The distance between where this fish was tagged and receiver 6 was a minimum straight-line distance of $80 \mathrm{~km}$. Movements of bonefish from the north side of the island going around the east end of the island also occurred. Two bonefish (\#08 and \#09) tagged in Zone 5 were detected at the east end of Grand Bahama (Table 1). Bonefish \#08 was detected on April 8, 2014 at receiver 15 , and then at receiver 16 on

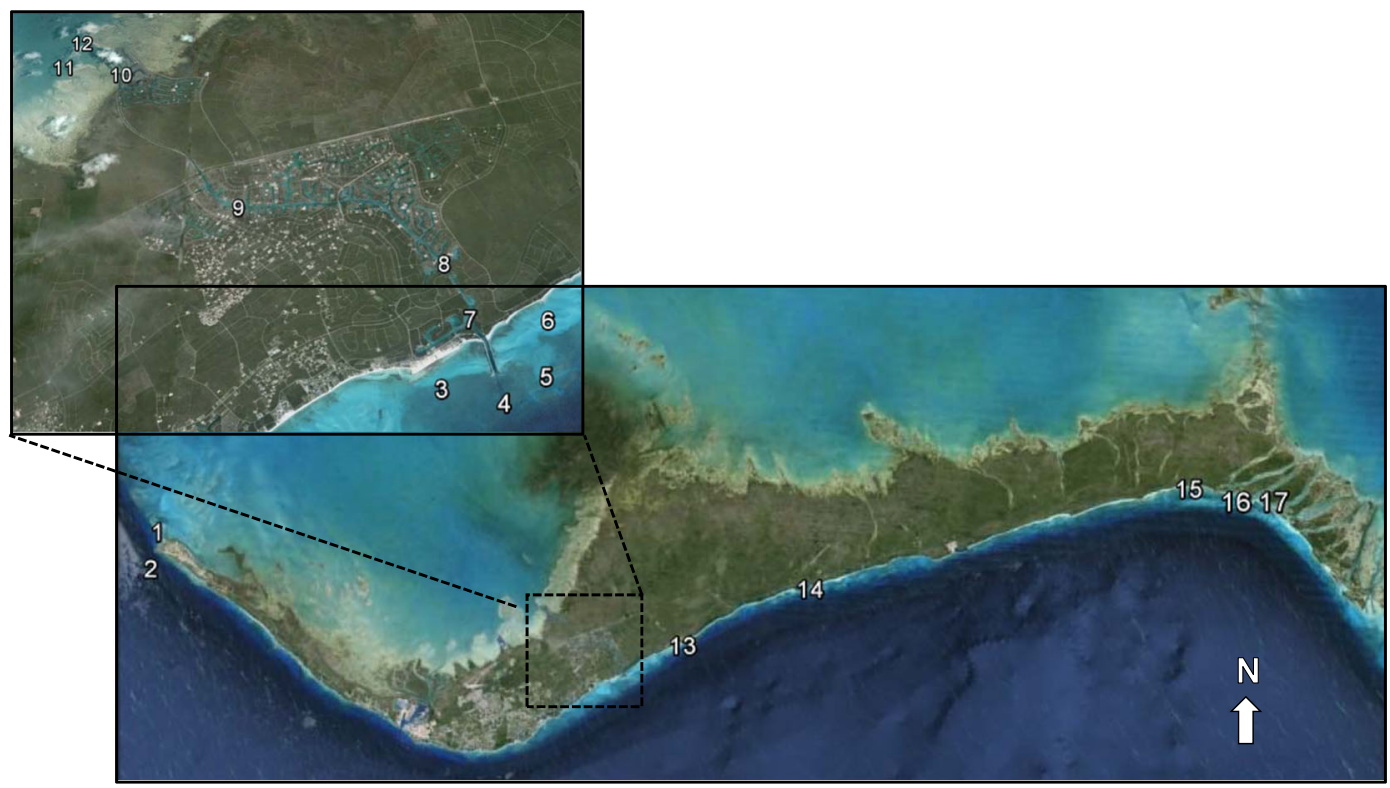

Fig. 3 Study area surrounding Grand Bahama showing the locations of the 17 receivers positioned to detect transmitter-implanted bonefish. The enlarged section of the map shows details of receiver placement within the Grand Lucayan Waterway 
Table 1 Summary of the tagging, biological, and monitoring data for the 30 adult bonefish used in this study
Receivers 1 and 2 are located at the west end of the island, receivers 3-6 are on the south entrance of the Grand Lucayan Waterway (GLW), receivers 7-10 are in the GLW, receivers 11 and 12 are on the north side of the GLW, receivers 13-14 are along the south coast of the island, and receivers 15-17 are on the east end of the island on the south side. See Fig. 3 for the exact placement of the receivers

\begin{tabular}{|c|c|c|c|c|c|c|}
\hline Zone & Date & Tag \# & $\mathrm{FL}(\mathrm{mm})$ & Sex & \# of detections & Receivers visited \\
\hline 1 & 2013-10-28 & 33 & 490 & $\mathrm{U}$ & 13 & 2,6 \\
\hline 1 & 2013-10-29 & 15 & 505 & $\mathrm{U}$ & 10 & 1,2 \\
\hline 1 & 2013-10-29 & 16 & 490 & $\mathrm{U}$ & 49 & $6,7,8,9,10,11,12,13,14$ \\
\hline 1 & 2013-10-29 & 17 & 440 & $\mathrm{U}$ & 0 & $\mathrm{n} / \mathrm{a}$ \\
\hline 1 & 2013-10-29 & 34 & 600 & $\mathrm{U}$ & 0 & $\mathrm{n} / \mathrm{a}$ \\
\hline 2 & $2013-10-28$ & 14 & 620 & $\mathrm{U}$ & 28 & $6,7,8,9,10,11,13$ \\
\hline 3 & 2013-10-26 & 24 & 655 & $\mathrm{U}$ & 2167 & $7,8,9,10,11,12,13$ \\
\hline 3 & 2013-10-26 & 25 & 550 & $\mathrm{U}$ & 56 & $6,7,8,9,10,12,13$ \\
\hline 3 & $2013-10-26$ & 26 & 465 & $\mathrm{U}$ & 0 & $\mathrm{n} / \mathrm{a}$ \\
\hline 3 & $2013-10-26$ & 35 & 574 & $\mathrm{U}$ & 1102 & $9,10,11,12$ \\
\hline 3 & 2013-10-26 & 36 & 618 & $\mathrm{U}$ & 116 & $6,7,8,9,10,12$ \\
\hline 3 & 2013-10-26 & 37 & 670 & $\mathrm{U}$ & 50 & $6,7,8,9,10,11,12,13$ \\
\hline 4 & $2013-10-25$ & 23 & 455 & $\mathrm{U}$ & 0 & $\mathrm{n} / \mathrm{a}$ \\
\hline 4 & $2013-10-26$ & 28 & 545 & $\mathrm{U}$ & 0 & $\mathrm{n} / \mathrm{a}$ \\
\hline 4 & 2013-10-26 & 29 & 550 & $\mathrm{U}$ & 0 & $\mathrm{n} / \mathrm{a}$ \\
\hline 4 & $2013-10-26$ & 30 & 560 & $\mathrm{U}$ & 2 & 12 \\
\hline 4 & 2013-10-26 & 31 & 539 & $\mathrm{U}$ & 55 & $6,7,8,9,10,11,12,13$ \\
\hline 4 & 2013-10-26 & 32 & 540 & M & 0 & $\mathrm{n} / \mathrm{a}$ \\
\hline 5 & $2013-10-27$ & 08 & 570 & $\mathrm{U}$ & 4 & 15,16 \\
\hline 5 & 2013-10-27 & 09 & 545 & M & 48 & $15,16,17$ \\
\hline 5 & 2013-10-27 & 10 & 515 & $\mathrm{U}$ & 0 & $\mathrm{n} / \mathrm{a}$ \\
\hline 5 & 2013-10-27 & 11 & 595 & $\mathrm{U}$ & 0 & $\mathrm{n} / \mathrm{a}$ \\
\hline 5 & $2013-10-27$ & 12 & 525 & $\mathrm{U}$ & 82 & $6,7,8,9,10,11,12,13$ \\
\hline 5 & 2013-10-27 & 13 & 610 & $\mathrm{U}$ & 0 & $\mathrm{n} / \mathrm{a}$ \\
\hline 6 & $2013-10-27$ & 18 & 510 & $\mathrm{U}$ & 171 & $6,7,8,13,14$ \\
\hline 6 & $2013-10-27$ & 19 & 580 & $\mathrm{U}$ & 508 & 6,13 \\
\hline 6 & $2013-10-27$ & 20 & 535 & $\mathrm{U}$ & 5678 & $6,13,14$ \\
\hline 6 & 2013-10-27 & 21 & 480 & $\mathrm{U}$ & 86 & $6,13,14$ \\
\hline 6 & $2013-10-27$ & 22 & 475 & $\mathrm{U}$ & 15806 & $5,6,7,13,14$ \\
\hline 6 & 2013-10-27 & 27 & 530 & $\mathrm{U}$ & 77 & $6,7,8,9,13,14$ \\
\hline
\end{tabular}

Fig. 4 Detections of bonefish \#22 within the telemetry array during the study period. This bonefish was tagged in Zone 6 on the south side of Grand Bahama and was detected only along the south side of the island during the study period

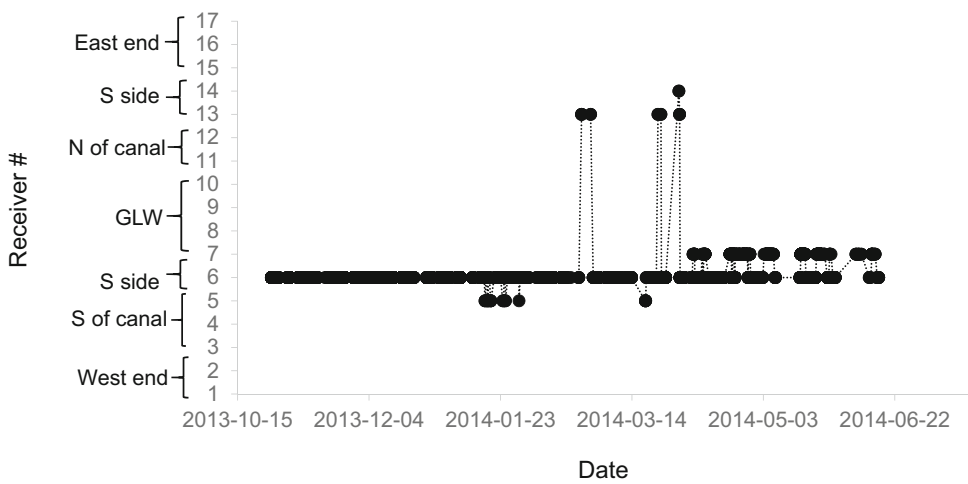


Table 2 Dates and moon phases corresponding to bonefish migration through the Grand Lucayan waterway

\begin{tabular}{lll}
\hline North-south migration dates & Moon phase & Fish tag \# \\
02-Feb-14 & 3 d after new moon & 24 \\
03-Feb-14 & 4 d after new mon & 12,37 \\
13-Feb-14 & 1 d before full moon & 31 \\
18-Mar-14 & 2 d after full moon & $12,24,25$ \\
19-Mar-14 & 3 d after full moon & 36 \\
23-Mar-14 & 1 d after last quarter & 14 \\
26-Mar-14 & 4 d before new moon & 31 \\
01-Apr-14 & 2 d after new moon & 16 \\
21-Apr-14 & $1 \mathrm{~d}$ before last quarter & 25 \\
25-Apr-14 & 3 d before new moon & 36 \\
South-north migration dates & Moon phase & Fish tag \# \\
05-Feb-14 & 1 d before first quarter & 12 \\
06-Feb-14 & first quarter & 24 \\
17-Feb-14 & 3 d after full moon & 31 \\
21-Mar-14 & 2 d before last quarter & $12,25,36$ \\
31-Mar-14 & $1 \mathrm{~d}$ after new moon & 31 \\
13-Apr-14 & 2 d before full moon & 16 \\
27-Apr-14 & $1 \mathrm{~d}$ before new moon & 36 \\
\hline
\end{tabular}

April 9, 2014. Detections fell one and 2 days after a first quarter moon. Bonefish \#09 was detected at the east end of Grand Bahama on a number of occasions (Fig. 6b). From January 11 to January 14, 2014, 12 detections were recorded between receivers 15 and 16, just prior to the January 15 full moon. On March 31, 2014, 1 day after the new moon, bonefish \#09 was detected two times at receiver 16. A single detection on April 8, 2014 was logged at receiver 15 , followed by 7 detections on receiver 16 and two detections on receiver 17 on April 10, 2014. From May 9 to May 19, 2014, bonefish \#09 was detected sporadically on receivers 15 and 16; dates which surround a full moon on May 14, 2014.

Manual tracking on the north side of Grand Bahama on February 1-2, 2014 revealed many transmitter implanted bonefish (\#08, \#12, \#36, \#37, and $\# 14$, \#15, \#34, respectively) close to their tagging locations. No additional data was garnered for tagged individuals on the south side of the island that wasn't already recorded by the receivers. However, during manual tracking on December 16, 2013, a large aggregation of bonefish (approximately 500 individuals) was spotted along the south shore (the specific location is not disclosed to protect potential prespawning aggregations). Within this aggregation, tagged bonefish \#21 was detected. The behaviour of fish in the aggregation included slowly swimming in a circle and dibbling at the surface. One fish was

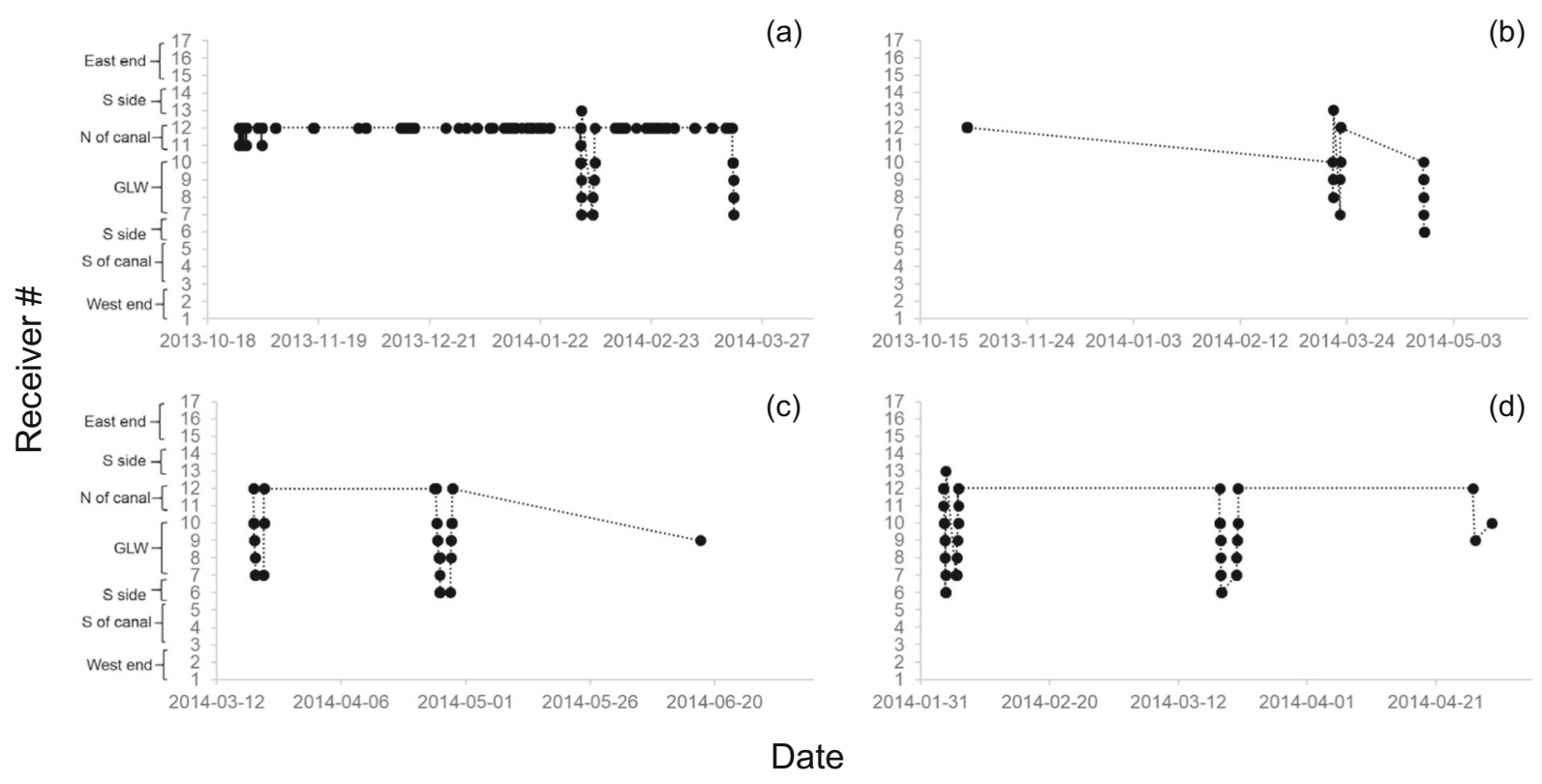

Fig. 5 Movement patterns of four of the eight bonefish tagged on the north side that fully used the Grand Lucayan Waterway to access water on the south side of Grand Bahama. Detections of bonefish \#24 (a), \#25 (b), \#36 (c), and \#12 (d) 


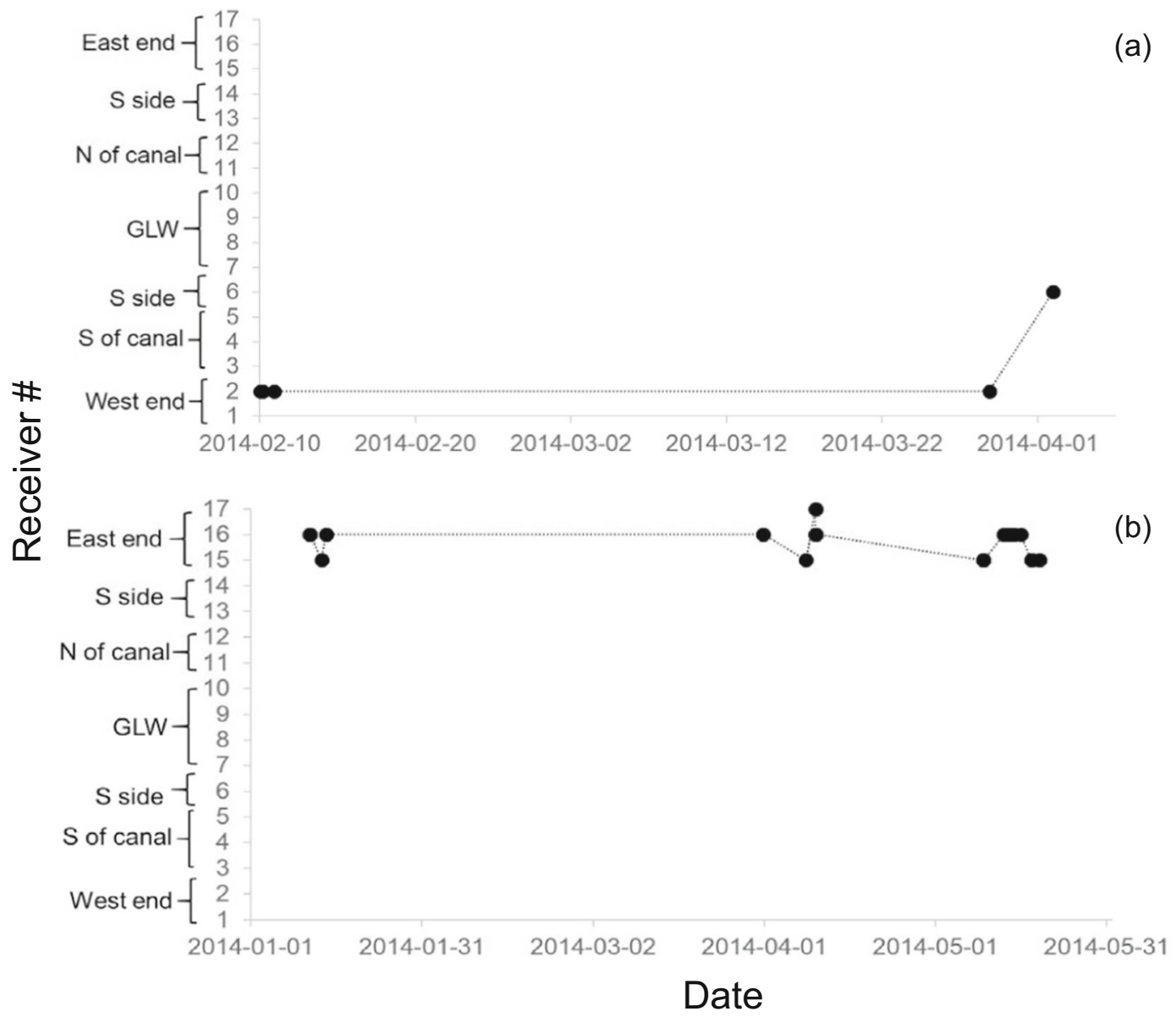

Fig. 6 a) Detections of bonefish \#33 within the telemetry array during the study period, showing movements to the west end of the array as well as along the southern shore of Grand Bahama. b)

angled from the aggregation and was determined to be a ripe male $(\mathrm{FL}=550 \mathrm{~mm})$ that was freely running sperm when tested manually. On December 17, 2013 we returned to this location on the south shore and the aggregation of bonefish was now approximately 800 individuals. Two single bonefish (i.e., outside of the school) were captured and sex could not be determined ( $\mathrm{FL}=555 \mathrm{~mm}$ and $595 \mathrm{~mm}$ ). One bonefish $(\mathrm{FL}=420 \mathrm{~mm})$ was captured amongst a school of sub-adult bonefish; sex could not be determined. Bonefish \#21 was not detected in the schools. The moon phase on December 17, 2013 was a full moon. Three individual bonefish (\#20,\#22, \#27) tagged in Zone 6 on the south side, travelled east on March 31, 2014, 1 day after a new moon and were detected by a receiver deployed in close proximity to the potential pre-spawning aggregation
Detections of bonefish $\# 09$ within the telemetry array during the study period, showing movements to the east end of the array

\section{Discussion}

This is the second telemetry project to occur in Grand Bahamian waters focused on characterizing the spatial ecology of bonefish. The first study was by Colton and Alevizon (1983), which focused on manual tracking 13 transmitter-implanted bonefish by boat around the east end of Grand Bahama. Out of 13 fish, only three were located after $24 \mathrm{~h}$, with two being monitored for a total of 16 and $30 \mathrm{~h}$, respectively, and one fish being tracked for a total of $32 \mathrm{~h}$ over a period of 100 days. Colton and Alevizon (1983) concluded that adult bonefish are very transient. Murchie et al. (2013) contradicted this finding after tracking 15 adult bonefish for periods exceeding 6 months around Eleuthera, and demonstrated that individuals show a continuum of fidelity between site attached and transient. The present study, although short 
term and specifically during the spawning season, also supports the findings of Murchie et al. (2013) with numerous individuals repeatedly being detected in one location followed by movements of greater distance. These movements of longer distance are likely occurring due to the spatial separation of bonefish feeding and breeding areas, a common phenomenon across taxa (Dingle and Drake 2007).

Bonefish use of the GLW and their movements around the east and west ends of the island typically occurred during a period of $1-4$ days prior to or after the full and new moons. These findings align with the results of Danylchuk et al. (2011) that found adult bonefish leave their typical shallow flats habitats and aggregate at locations close to deep-water drop-offs near the Exuma Sound during a period of 4-7 days spanning full and new moon. The association with new and full moon phases, which bring relatively strong tides, could be beneficial for spawning fish in that their pelagic larvae could be dispersed greater distances (Doherty et al. 1985; Domeier and Colin 1997). It is quite possible that we located a pre-spawning aggregation via manual tracking as some of the observed behaviours matched that of pre-spawning aggregations in Eleuthera; specifically the lack of feeding by members of the school (Danylchuk et al. 2011). Individuals captured in and around this school were determined to be running males, ready for spawning. This location along the south shore is $1.5 \mathrm{~km}$ to a $61 \mathrm{~m}$ drop off in the Northwest Providence Channel, which is also a key feature for pre-spawning aggregation and spawning site locations, according to Danylchuk et al. (2011). While we did not observe other characteristic behaviours of pre-spawning aggregations such as porpoising and ventral nudging (Danylchuk et al. 2011), our observations took place well before dusk. Future studies will include more manual tracking at various times of the day to determine potential prespawning aggregations.

The loss of Hawksbill Creek as a migration route between the north and south side of Grand Bahama appears to be somewhat mitigated by the use of the GLW, at least for bonefish. Historically, fish located around Zone 1 would have had a shorter distance to travel for a north-south migration route than present day bonefish. In this study, two fish tagged in Zone 1 travelled to the west end of the island and one fish went through the canal. For bonefish \#33, going west and continuing on to where receiver 6 was located, would have required a minimum swimming distance of approximately $80 \mathrm{~km}$. Bonefish \#16 however, also tagged in Zone 1, travelled through the canal to receiver 13 , which was east of receiver 6 , and had a minimum distance of $36 \mathrm{~km}$. Routes that minimize energy expenditure during migration would presumably benefit an individual as the energy saved could go towards foraging, growth, or predator avoidance, allowing the fish to manage its energy economics and ultimately increase its fitness (Ricklefs 1976).

Differences in movement corridors were also observed for fish in Zone 5. Two individuals travelled along the north shore to reach the east end and south side of Grand Bahama, while one individual used the canal to access the south side around Zone 6. It is possible that there are a number of additional prespawning aggregation locations, and the east end of Grand Bahama near receiver 15 is a short $(2.5 \mathrm{~km})$ distance to deep-water drop-offs. Bonefish \#33 from Zone 1, which travelled around the west end and along the south shore to east of the GLW (approximately $80 \mathrm{~km}$ ), could have potentially chosen this route to participate in spawning at multiple locations. Because it will also be important to protect spawning bonefish, future studies should determine the location of additional pre-spawning aggregations as well as spawning sites.

Collectively these results demonstrate the importance of near-shore areas along the coast of Grand Bahama as important movement corridors for adult bonefish during their spawning season. This study also suggests that despite historical habitat modifications, bonefish today use the GLW as a movement corridor. Indeed, the approach used here is certainly transferrable and would be useful to understand how bonefish and other coastallyoriented fish species interact with other human-altered habitats. Although the GLW was not conceived as fish habitat, it needs to be managed as such in the future. This study (like a growing number of telemetry studies; Lapointe et al. 2013) has also revealed opportunities for habitat enhancement. For example, replacement of hardened engineered shorelines with more natural habitats could further improve connectivity of the GLW for bonefish and other aquatic animals. Like so many other recreationally and commercially important species, bonefish use many habitats throughout their life cycle, and the protection of these habitats, especially movement corridors to potential spawning sites, is important for sustainability of these populations in the future. Any development activities that would further alter habitat or degrade water quality could impede connectivity and 
threaten the health of the multi-million dollar bonefish fishery, along with many other ecologically and economically important coastal fisheries.

Acknowledgments We gratefully acknowledge the significant contribution of effort from the guides of h2obonefishing - without their expertise and assistance this study would not have been possible. Leroy Robinson, Colleen and Larry Lewis, Malcom Goodman, and Kelly Hannan provided logistical support. Godfrey Waugh, Keith Cooper, Levette Morris, Edith Gibson, and Christopher Bull provided assistance with historical accounts of Grand Bahama. The Fisheries Conservation Foundation, Cape Eleuthera Institute, The University of Illinois at Urbana-Champaign, The Bahamas Department of Marine Resources, and The Bahamas National Trust are also acknowledged for their support of the study. Cooke is supported by the Canada Research Chairs Program, Bonefish and Tarpon Trust and the Natural Sciences and Engineering Research Council of Canada. All methods used in this study were in accordance with the policies of the Canadian Council on Animal Care as administered by the Carleton University Animal Care Committee (Protocol B10-06).

\section{References}

Adams AJ, Hordysky AZ, McBride RS, MacDonald TC, Shenker J, Guindon K, Harwell HD, Ward R, Carpenter K (2013) Conservation status and research needs for tarpons (Megalopidae), ladyfishes (Elopidae), and bonefishes (Albulidae). Fish Fish 15:280-311

Alongi DM (2002) Present state and future of the world's mangrove forests. Environ Conserv 29:331-349

Ault JS (2008) Biology and management of the world tarpon and bonefish fisheries. CRC Press, Boca Raton

Barratt P (2002) Grand Bahama - A rich and colourful history, 3rd edn. IM Publishing, Freeport

Buchan KC (2000) The Bahamas. Marine Poll Bull 41:94-111

Coleman FC, Koenig CC, Collins LA (1996) Reproductive styles of shallow-water grouper (Pisces:Serranidae) in the eastern Gulf of Mexico and the consequences of fishing spawning aggregations. Environ Biol Fish 47:129-141

Colton DE, Alevizon WS (1983) Movement patterns of the bonefish (Albula vulpes) in Bahamian waters. Fish Bull 81:148-154

Danylchuk AJ, Cooke SJ, Goldberg TL, Suski CD, Murchie KJ, Danylchuk SE, Shultz A, Haak CR, Brooks E, Oronti A, Koppleman JB, Philipp DP (2011) Aggregations and offshore movements as indicators of spawning activity of bonefish (Albula vulpes) in The Bahamas. Mar Biol 158:1981-1999

Dingle H, Drake A (2007) What is migration? Bioscience 57:113121

Doherty PJ, Williams DM, Sale PF (1985) The adaptive significance of larval dispersal in coral reef fishes. Environ Biol Fish 12:81-90

Domeier ML, Colin RL (1997) Tropical reef fish spawning aggregations: defined and reviewed. Bull Mar Sci 60:698-726

Dupuch SP (1971) Bahamas handbook and businessman's annual 1971-72. Etienne Dupuch Jr publications, Nassau
Engstrom NA (1984) Depth limitation of a tropical intertidal xanthid crab, Cataleptodius floridanus, and a shallow-water majid, Pitho aculeate: results of a cagingexperiment. J Crustac Biol 4:55-62

Faunce CH, Serafy JE (2006) Mangroves as fish habitat: 50 years of field studies. Mar Ecol Prog 318:1-18

Fedler A (2010) The economic impact of flats fishing in The Bahamas. Report to the Everglades Foundation. $16 \mathrm{p}$

Feller IC, Lovelock CE, Berger U, McKee KL, Joye SB, Ball MC (2010) Biocomplexity in mangrove ecosystems. Ann Rev Mar Sci 2:395-417

Halpern BS, Walbridge S, Selkoe KA, Kappel CV, Micheli F, D'Agrosa C, Watson R (2008) A global map of human impact on marine ecosystems. Science 319:948-952

Heupel MR, Semmens JM, Hobday AJ (2006) Automated acoustic tracking of aquatic animals: scales, design and deployment of listening station arrays. Mar Freshw Res 57:1-13

Johannes RE, Yeeting B (2000) I-Kiribati knowledge and management of Tarawa's lagoon resources. Atoll Res Bull 498:1-24

Lapointe NWR, Thiem JD, Doka SE, Cooke SJ (2013) Opportunities for improving aquatic restoration science and monitoring through the use of animal electronic-tagging technology. Bioscience 63:390-396

Lotze HK, Lenihan HS, Bourque BJ, Bradbury RG, Cooke RG et al (2006) Depletion, degradation, and recovery potential of estuaries and coastal seas. Science 312:1806-1809

McElroy JL, de Albuquerque K (1998) Tourism penetration index in small Caribbean islands. Ann Tour Res 25:145-168

Murchie KJ, Cooke SJ, Danylchuk AJ, Danylchuk SE, Goldberg TL, Suski CD, Philipp DP (2013) Movement patterns of bonefish (Albula vulpes) in tidal creeks and coastal waters of Eleuthera, The Bahamas. Fish Res 147:404-412

Musick JA, Harbin MM, Berkeley SA, Burgess GH, Eklund AM, Findley L, Gilmore RG, Golden JT, Ha DS, Huntsman GR, McGovern JC, Parker SJ, Poss SG, Sala E, Schmidt TW, Sedberry GR, Weeks H, Wright SG (2000) Marine, estuarine, and diadromous fish stocks at risk of extinction in North America (exclusive of Pacific salmonids). Fisheries 25:6-30

Nagelkerken I, Blaber SJM, Bouillon S, Green P, Haywood M, Kirton LG, Somerfield PJ (2008) The habitat function of mangroves for terrestrial and marine fauna: a review. Aquat Bot 89:155-185

Polidoro BA, Carpenter KE, Collins L, Duke NC, Ellison AM et al (2010) The loss of species: mangrove extinction risk and geographic areas of global concern. PLoS ONE 5(4), e10095. doi:10.1371/journal.pone.0010095

Ricklefs RE (1976) The economy of nature. Chiron Press, Portland

Roberts CM, Hawkins JP (1999) Extinction risk in the sea. Trends Ecol Evol 14:241-246

Sala E, Aburto-Oropeza O, Paredes G, Thompson G (2003) Spawning aggregations and reproductive behavior of reef fishes in the Gulf of California. Bull Mar Sci 72:103-121

Sullivan Sealy K, Brunnick B, Harzen S, Luton C, Nero V, Flowers L (2002) An ecoregional plan for the Bahamian archipelago. Taras Oceanographic Foundation, Jupiter

US Army Corps of Engineers (2004) Water resources assessment of The Bahamas. US Army Corps of Engineers, Mobile District and Topographic Engineering Center, December 2004, 114 pp

Wagner GN, Cooke SJ, Brown RS, Deters KA (2011) Surgical implantation techniques for electronic tags in fish. Rev Fish Biol Fish 21:71-81 